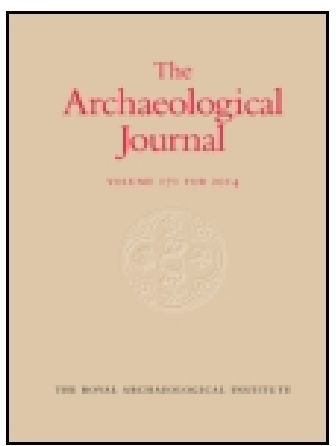

Archaeological Journal

\title{
On the Late, or Debased, Gothic Buildings of Oxford
}

\section{O. Jewitt}

To cite this article: O. Jewitt (1851) On the Late, or Debased, Gothic Buildings of Oxford, Archaeological Journal, 8:1, 382-396, DOI: 10.1080/00665983.1851.10850831

To link to this article: http://dx.doi.org/10.1080/00665983.1851.10850831

曲 Published online: 10 Jul 2014.

Submit your article to this journal $๘$

Џ Article views: 4

Q View related articles $\sqsubset$ 
" ad valli marginem," and therefore the words " duplici vallo," or double ditch, imply to my mind that the work was twofold, enceinte and envelope ; moreover, the introduction of the plate in 1674, shows that it was intended to represent the fortifications that were really made, not merely such as were suggested. The difference between the Latin translation and Wood's own manuscript, appears to have arisen from the following cause : the Latin translation is not from Wood's own pen, it was made by one Richard Peers, a student of Christ Church, who offended Anthony a Wood by permitting Dr. Fell to insert passages not in the original; but where one can detect no motive for alteration, save a regard for the preservation of facts, I am ready to receive and acknowledge him as worthy of credit, and believe the works at Oxford to have been such as are represented in the plan which he has given,--such as never before or since were constructed in England, or, as far as I am aware, in any other country.

GIBBS RIGAUD,

Capt. 60th Reg. Royal Rifles.

ON THE LATE, OR DEBASED, GOTHIC BUILDINGS OF OXFORD.

FROM THE REIGN OF ELIZABETH TO THE END OF THE SEVENTEENTII CENTURY.

READ AT THE MEETING OF THE ARGHAOLOGICAL INSTITUTE AT OXFORD, JUNE, 1850.

GoTHIC A rchitecture seems to have attained its ultimate perfection in the fourteenth century, at which period every thing belonging to it was conceived and executed in a free and bold spirit, all the forms were graceful and natural, and all the details of foliage and other sculptures were copied from living types, with a skill and truth of drawing which has never been surpassed. Conventional forms were in a great measure abandoned, and it seems to have been rightly and truly considered that the fittest monuments for the House of God were faithful copies of His works, and so long as this principle continued to be acted on, so long did Gothic Architecture remain pure. But in the succeeding century, under the later Henrys and Edwards, a gradual decline took place, everything was moulded to suit a preconceived idea, the foliage lost its freshness, and was moulded into something of a rectangular form, the arches were depressed, the windows 
lowered, the flowing curves of the tracery converted into straight lines, panelling profusely used, and the square form everywhere introduced; until at length the prevalence of the horizontal line led easily and naturally to the renaissance of the classic styles, though in an impure and much degraded form. The mixture of the two styles first appears in the time of Henry VII., a period in which, (though remarkable for the beauty and delicacy of its details) the grand conceptions of form and proportion of the previous century seem to have been lost. Heaviness or clumsiness of form, combined with exquisite beauty of detail, are the characteristics of this era.

In the time of Henry VIII. the details also became debased, and there was a greater mixture of Italian work, but still the Gothic ideas predominated, and there are some good examples of this date remaining, of which the Hall of Christ Church may be adduced as a proof.

In the reign of Elizabeth the mixture of the two styles was more complete, and though the details were frequently incongruous, there resulted from the union a style which when applied to domestic buildings was highly picturesque, and occasionally produced great richness of effect. ${ }^{1}$

In the succeeding period the decline still continued, feature after feature was lost, until at length all was swallowed up by its rival. That feature, however, which was always the most important and most characteristic of Gothic Architecture, and on which at all periods the distinctions of the styles chiefly depended, namely, the window, was the last to depart, for when every other trace of the style was lost, we find the windows still retaining either their Gothic form or their Gothic tracery, and thus evincing the lingering love which was still felt for the ancient forms.

During all this period of decline however, frequent attempts were made to stay its progress, and in no place more successfully than in Oxford, as the number of buildings of this period will testify. To point out the peculiarities, and to give the most remarkable points of the history of these buildings will be the subject of the present paper, the his-

${ }^{1}$ A curious example of Elizabethan work occurs at Sunningwell Church within a few miles of Oxford, where there is a singular polygonal porch at the west end, being a mixture of Ionic columns and Gothic windows. There is also some good woodwork of the same period. The church was chiefly rebuilt by Bishop Jewel. 
torical facts of which are taken chiefly from Dr. Ingram's Memorials of Oxford, and from Anthony a Wood.

The first building of this period which claims attention is the Bodleian Library, and in order to understand the history of this it will be necessary to go a little further back. It seems that various donations of books had been made by different individuals in the 13 th and 14 th centuries, but that no proper depository had been provided for them, and that they remained either locked up in chests or chained to desks in the Old Congregation-house, and in the various chapels of St. Mary's Church, until a room or "solar" having been built for them by Bishop Cobham in 1320, over the old congregation-house, they were after various disputes removed there in 1409. It seems too that the University had at this time fallen into great irregularity, and suffered great inconvenience from the want of public authorised schools; the various professors using for that purpose apartments in private houses in various parts of the city. This led to the erection of a building for that purpose in 1439, and about the same time the University resolved to erect a separate School for Divinity, on a large scale in a central situation near the other schools. Liberal contributions having been made by various persons, and especially by Humphrey, Duke of Gloucester, son of Henry IV., they were enabled about the year 1480, not only to complete the Divinity School as it now stands, but to build the room over it for a library, and from the circumstance of the Duke being the principal donor both in his life-time and at his death, and of his bequeathing a number of valuable manuscripts, he is styled the founder, and the Library was called by his name. Into this library the books from St. Mary's were removed. ${ }^{2}$

The Divinity School yet remains in much the same state as when built, except that a doorway was made by Sir Christopher Wren, under one of the windows of the north side for the convenience of processions to the Theatre, and that at the east end the door-way has been altered externally. On examination it will be found that the outer mouldings have been cut down even with the wall, and from the marks on the wall it seems probable that there was a groined porch

2 The workmen employed were the same as were employed at Eton and Windsor under the direction of William of Waynfleet, and were called away from

here under a royal mandate, but were restored again in consequence of a peti. tion from the University. 

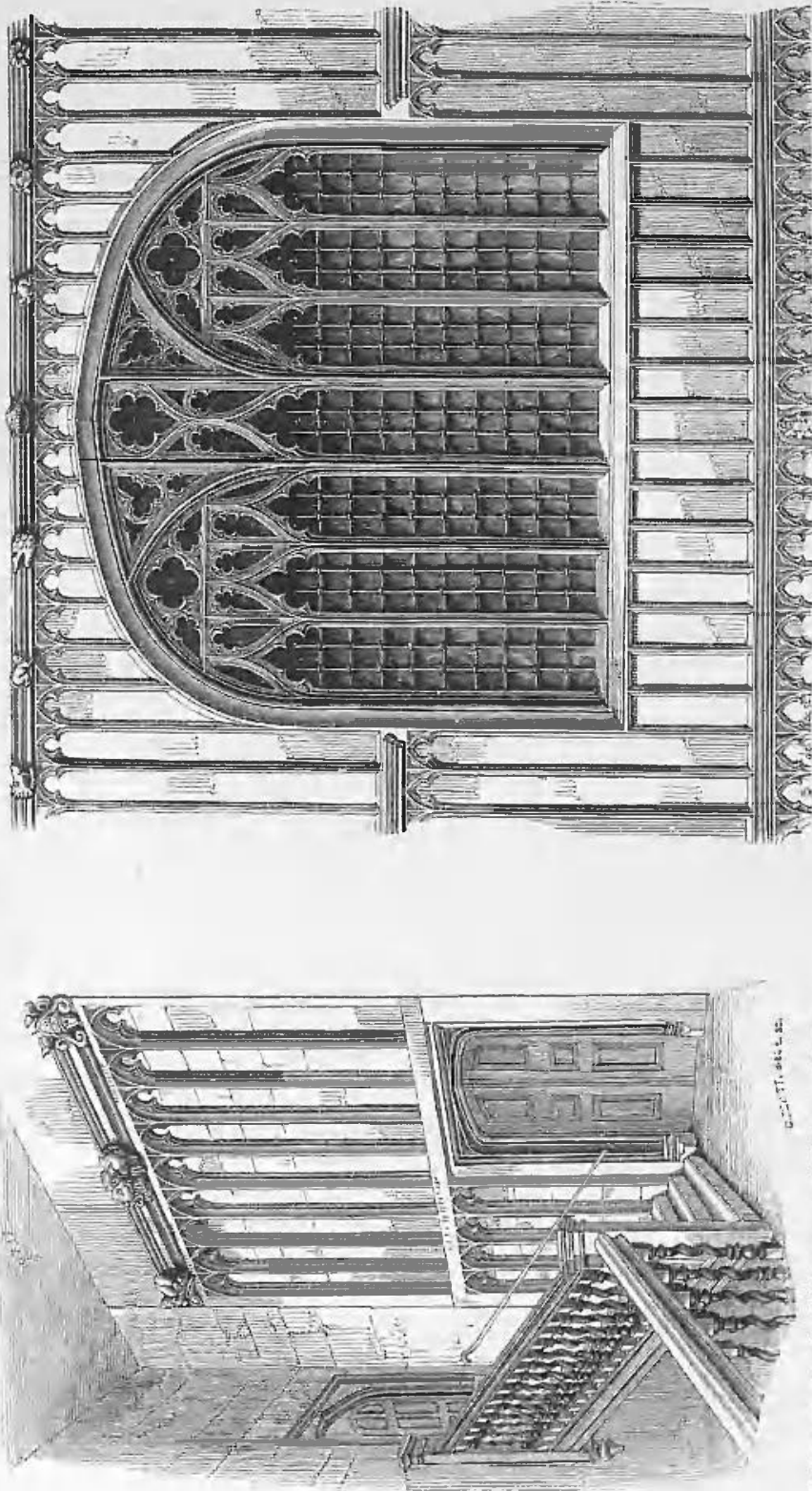
EXAMPLES OF LATE GOTHIC BUILDINGS IN OXFORD.
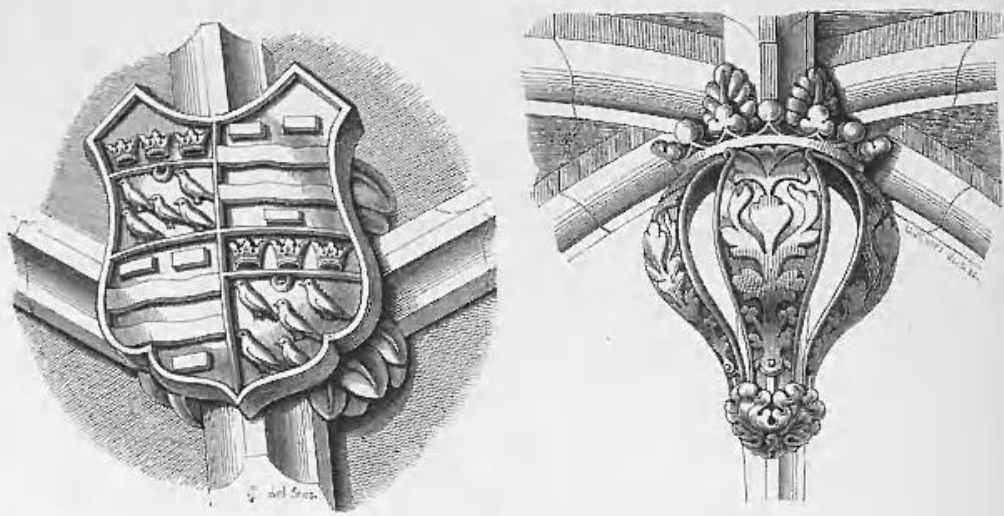

Bostes.

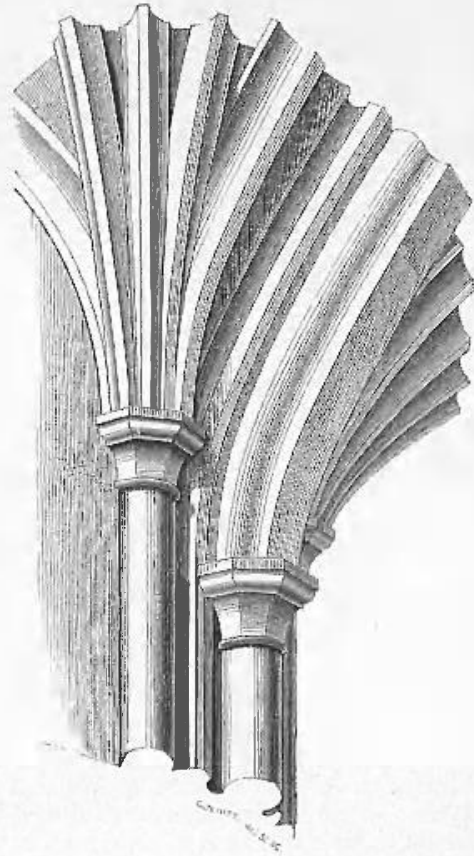

Impost.

DETAIJS OF THE PROSCHOLIUM OF THE DIVINITY SCHOOL. 
projecting in this direction, and that this was removed to make way for the covered walk, or Proscholium, when the Bodleian Library was built.

After the Reformation the schools appear for some years to have been almost deserted and in ruins, until, in the reign of Elizabeth, in the year 1597, Sir Thomas Bodley, a gentleman of a Devonshire family, who had been educated in the University, (and who had afterwards travelled through most parts of Europe, and been employed by Queen Elizabeth in many important matters,) resolved, as he tells us himself, to "set up his staff at the Library door at Oxford," and restore the place to the use of students. He commenced the same year the Restoration of Duke Humphrey's Library, which he repaired and refitted, and to which he added a new roof; and afterwards, in 1610, commenced building the Library which now bears his name, but which he did not live to see finished. ${ }^{3} \quad$ This new building he placed at the east end of, and transversely to, the Divinity School, the north-east and south-east buttresses being built into the new wall, and leaving in front of the east door the Proscholium or covered walk already mentioned, popularly known as the "Pig Market." Of this Wood says, "In which Ambulachrum do stand such that are candidates for, or sue after, their graces to the Regents sitting in the Congregation House adjoining." The reason of this being, that any requisite questions might be put to them previous to granting the degrees, a practice which was discontinued when the system of public examinations was introduced. ${ }^{4}$ It was necessary, therefore, in making the new building, to retain this space, and the present groined room was formed accordingly. It is lighted by a window at each end, one of which is not nor has ever been intended to be glazed. It has a vaulted ceiling, with bosses at the intersections, the alternate ones being shields

3 The architect employed was Thomas Holt of York, who was likewise employed orer several of the other buildings in Oxford at the same period. He died in 1624, and was buried in Holywell Churchyard. The builder's were first, J. Acroid, who died in 1613 , and afterwards J. Bentley, who built likewise the new buildings of Merton, and M. Bentley, who died in 1618 .

${ }^{4}$ From this arose the popular but erroneous belief that the candidates were compelled to walk an hour in the Pigmarket in order to allow the tradesmen to whom they were indebted to recognise them and obtain payment of their debts, it being a rule that no candidate against whom an action for debt is pending in the University court, can receive a degree. But though the belief was not correct, it was untila comparatively recent period the custom for tradesmen to attend at those times for the purpose mentioned. 
with the arms of the founder. ${ }^{5}$ Some of the bosses are of good design and execution, but others are of late character. The general effect is good, but the details, particularly the mouldings, are of very debased character.

The buttresses of the Divinity School are panelled the greater part of their height, and one of these, as has been mentioned before, is built in, and forms part of Bodley's new wall, so that the panelling is visible on both sides, but on the east end it is carried forward on the face of the wall, as far as the point from which the porch seems to have projected, and it is tolerably evident from the remains of the shafts which have been cut away, and from other marks on the wall, that this porch must have been groined. It seems to have been the wish of Bodley to have his new building to agree in character with the old, and he therefore had the whole of his building panelled in the same manner as the Divinity School. This forms the west side of the School's Quadrangle, ${ }^{6}$ and is different in character from the rest of the buildings. The width of the quadrangle of the schools is greater than the length of the fron $\mathrm{i}$ of the Bodleian, and therefore a few feet had to be added at each end of Bodley's work. This may be seen inside these staircases, particularly between the entrances to the Bodleian and the Picture Gallery, where the old work is panelled, and has a corbel table the same as the rest of the front, but the new work is plain. The upper story of this building joins Duke Humphrey's Library, and is lighted by a large window at each end, and another opposite the old library. This window is a curious combination of mullions, transoms, and tracery of different forms. The rest of the windows are small.

Sir Thomas Bodley, shortly before his death, had conceived and matured the plan of a new building for the Public Schools of the University, and everything was settled for carrying the plan into execution, but he did not live to see it commenced. He died at his house in London in 1613, and was brought to Oxford, and buried in Merton College Chapel on the 29th of March in that year, and the day after the

5 Quarterly, I and 4, Argent five martlets saltier-wise sable; on a chief azure, three ducal coronets, or ; a crescent for difference. Bodley. 2 and 3 , Argent, two bars wavy, between three billets sable. Hore.

6 The two staircases were added after wards, but were panelled to match the rest of the work. On the north end this panelling seems to have been subsequently cut away, so that nothing but the small arches remain attached to the under side of the strings. In Williams's Oxonia Depicta it is shown completely panelled. 
EXAMPLES OF LATE GOTHIC BUILDINGS IN OXFOBD.

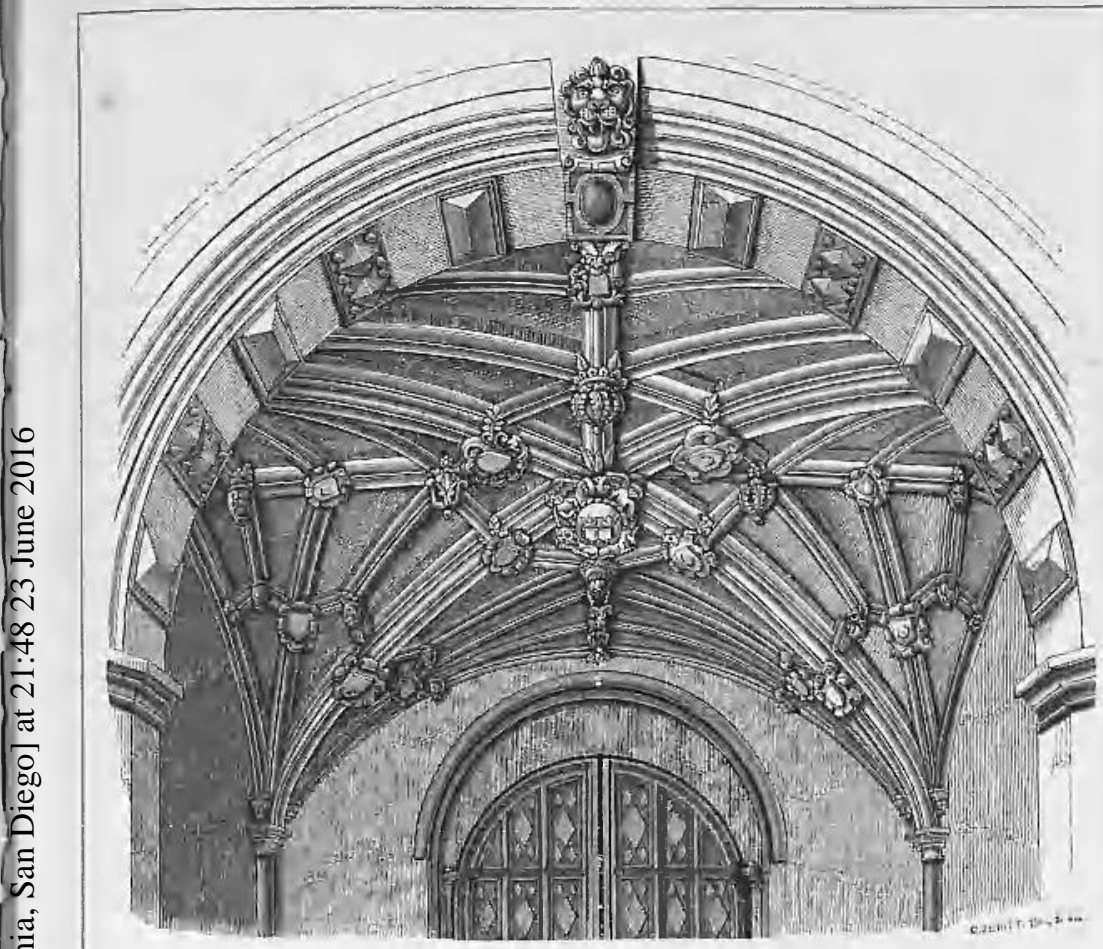

Groining.

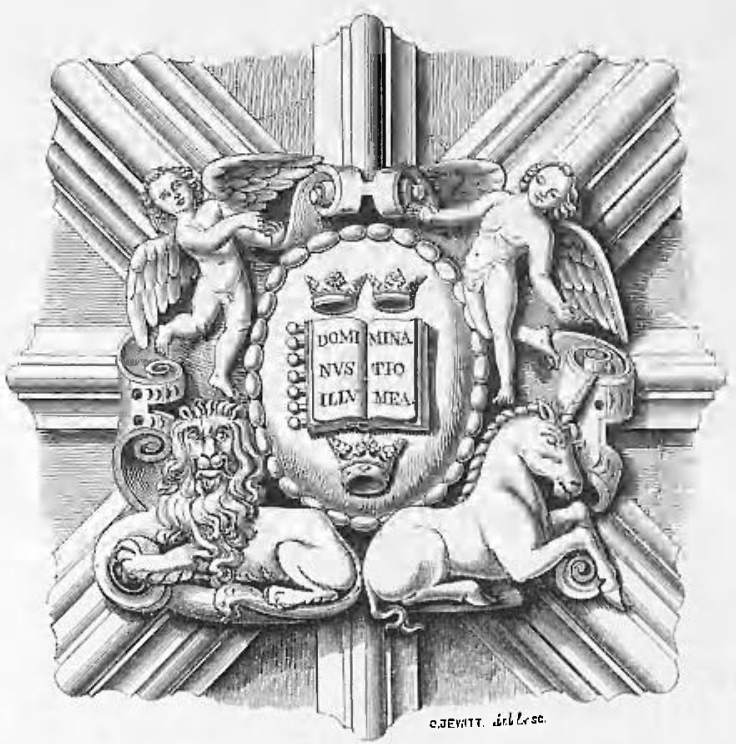

Central Boss.

GATEWAY OF THE SCHOOLS. 
funeral the first stone of the new Schools was laid, the building of which occupied the next six years.

This building, which, with the Bodleian Library for its west side, forms a complete quadrangle, is plain, poor, and heavy in its general appearance, and little skill has been displayed in giving either variety of outline or of light and shade. This plainness is still further increased by the removal of the transoms with which the windows were originally furnished, and which are still retained in those in the tower. The Gateway Tower on the east side, which afforded an opportunity for this, is not distinguished by any projection from the flat wall, but merely rises above the parapet on the same plane. The oriel, too, over the doorway, which might have given effect, is tame and poor. The whole mass is square, without buttresses or any other projection to relieve it. In the inner front of the Tower, however, more pains have been taken; the five stories into which it is divided are each ornamented with columns of one of the five classic orders, the plinths, friezes, and the shafts for a third of their length being covered with the peculiar Arabesque of the period, intermixed with the national emblems, \&c. In the fourth story is a figure of James I., and the whole is surmounted with a parapet of open scroll-work enclosing the royal arms. These figures were originally gilt. Taken altogether this composition is a favourable specimen of the style of that time, though it does not harmonise with the Gothic turret and pinnacle which rise above it. The archway is groined, and is a curious example, the bosses being all more or less of Elizabethan design. The wooden door is panelled, the panels being filled with the arms of the various colleges as late as Wadham, that being then newly erected. ${ }^{7}$

An addition was made at the west end of the Divinity School, 1634 to 1640 , the lower part of which is the Conro-

7 Anthony a Wood's description of this gateway is so good in its way, and harmonises so completely with jis subject, that it is here given complete.

"But between the geometry and metaphysic, and astronomy and logic schools, is the clief entrance from Cat Street into this new fabric; having over it an eminent and stately tower, wherein are contained, beside the vault or entrance, four rooms; the first is the mathematical library for the use of the Savilian pro- fessors; the second is part of the gallery; the third, the muniments and registers of the university; and the fourth, which is the uppermost, doth serve for astronomy uses. On the outside of the said tower, next to the area, or quadrangle, is beheld the rise of five stories of pillars (equal to every story of the tower), viz., of Thuscan, Doric, Ionic, Corinthian, and Composite work. Between the upper story of pillars saving one is the effigies of King James I. cut very curiously in stone, sitting on a 
cation House, and the upper part an addition to the library for containing the books of the learned Selden, and is called by his name.

The next building in order of time is Wadham College, which was commenced in 1610, and completed in 1613, the year in which the Schools were commenced. It was founded by Sir Nicholas and Dame Dorothy Wadham, (whose effigies appear over the doorway of the hall,) but was not commenced till after the death of Sir Nicholas in 1609. The building was commenced in 1610 , and the whole of the quadrangle, the hall and chapel, were completed in 1613.

The general character of the buildings of the quadrangle is the same as that of the Schools, having a tower, gateway, and oriel window in the same situation, but the hall and ante-chapel are of somewhat different character, having debased tracery in the windows formed of scroll-work, and of which the large window of the hall is a very curious example. But the most singular part is the chapel, which is totally different in style from the rest of the buildings; the windows have good perpendicular tracery and mouldings, though of rather late character, and there is little to distinguish it from a pure perpendicular building except the upper mouldings of the buttresses. In the east window, however, there is a singularity in the subordination of the tracery which would not have occurred in the best period of perpendicular. The two mullions of the centre light are carried through the head and on each side in the sub-arches. The other two mullions are not carried through, but another rises from the second and fourth lights, cutting through the sub-arches, and by this means the primary tracery, not

throne, and giving with his right hand a book to the picture or emblem of Fame,

with this inscription on the cover :

\section{"HAC HABEO QUA SCRIPSI.}

"With his left hand he reacheth out another book to our mother, the University of Oxford, represented in effigie, kneeling to the IFing, with this inscription on the cover also:

" HAC HABEO QUA DEDI.

" On the verge of the canopy over the throne, and the King's head, which is also most admirably cut in stone, is his motto, "Beati pacifici.

“ Over that also are emblems of Justice,
Peace and Plenty, and underneath all, this inscription in golden letters :

\section{“Regnante D, Jacobo Reguir Doctissiyo

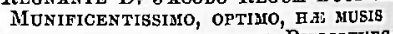 \\ Extructer Moles, CONGesta Bibliotieca,} ET QU FCUNOIE ADHUO DEERANT AD SPLENDOREY ACADEMI $x$ GELICITEN TENTATA,

Coepta absoldta. Soli Deo gloria.

"All which Pictures and Emblems were at first with great cost and splendour double gilt; but when K. James came from Woodstock to see this quadrangular pile, commanded them (being so glorious and splendid that none, especially when the sun shines, could behold them) to be whited over, and adorned with ordinary colours, which hath since so continued." Vol. iii. p. 793. 
EXAMPLES OF LATE GOTHIC BUILDINGS IN OXFORD.

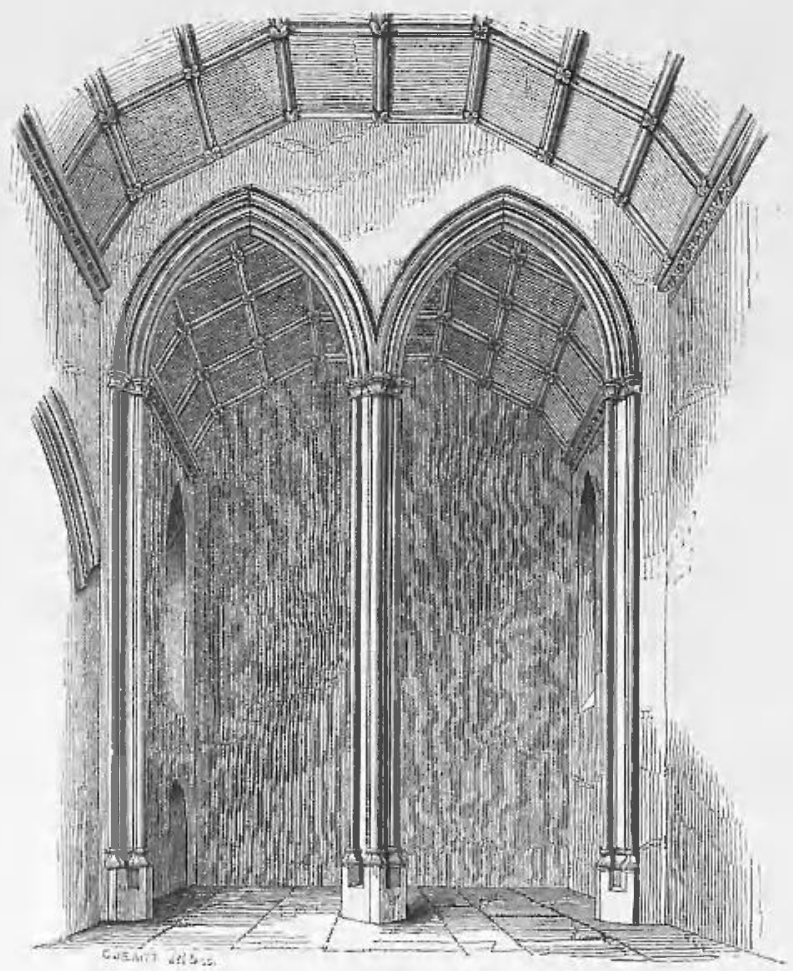

Arches of the Ante-Chapel.

WAD HA II GOLLEGE. 


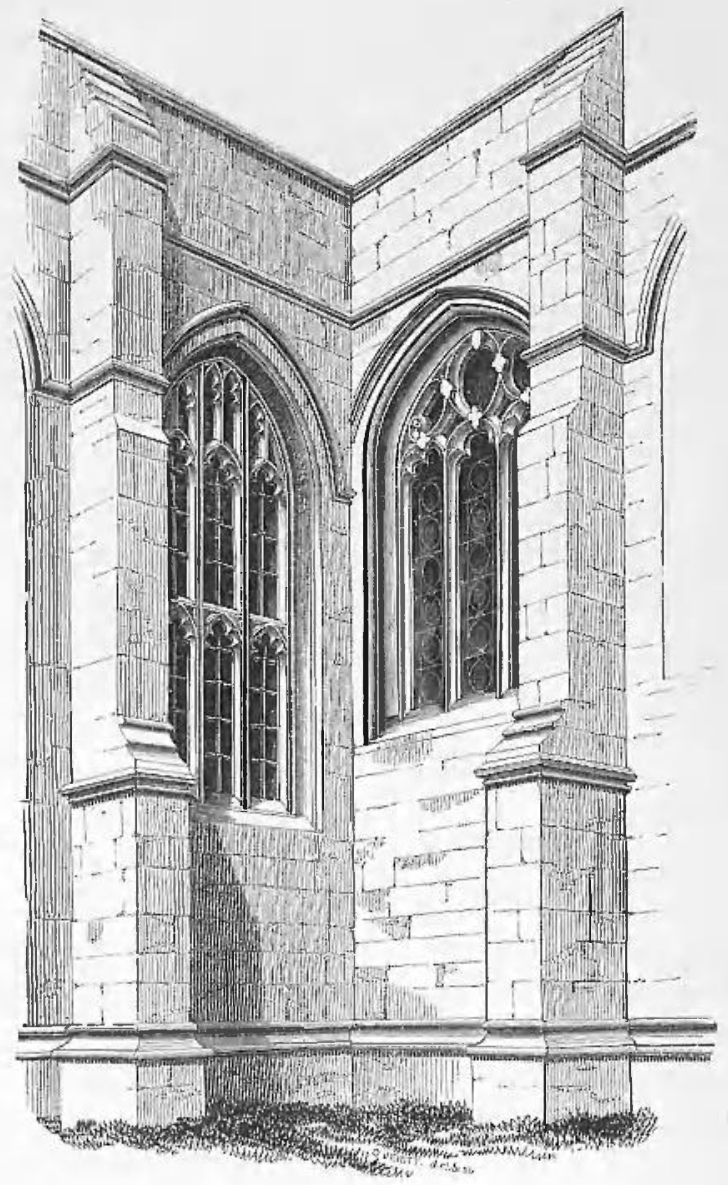

Windorrs of the Chapel and Ante-Chapel.

WADHAM COLLEGE. 
being equally distributed over the space, produces an awkward effect, though the window has evidently, but not skilfully, been copied from those of New College. The side windows are of three lights with transoms, and are good in all their details; and there are in the interior two lofty arches, which divide the ante-chapel from the transept, and which are of the same character, and are also an imitation of those in New College. The rest of the ante-chapel corresponds with the hall, so that it produces one uniform front towards the quadrangle. The character of this part is totally different to that of the chapel; and the contrast of the two (shown in the woodcut), is very striking. The tracery of the one is good perpendicular, but that of the other is of a kind unknown to Gothic. It is composed of scroll-work in elliptic forms, and with a kind of flat bosses at the intersections. The mouldings, too, are totally different, one not differing much from the usual

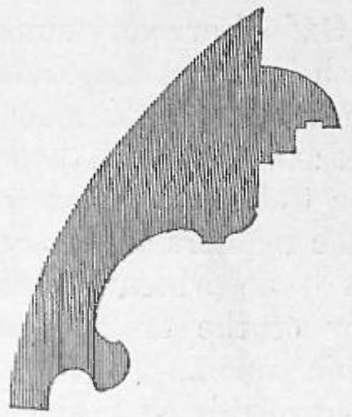

Section of Window. Chapel, Wadham College.

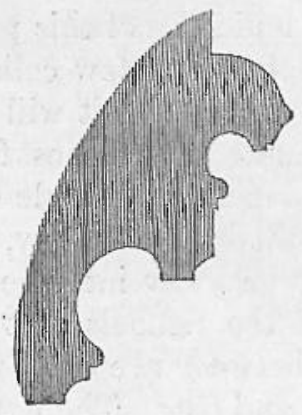

Section of Window Ante-Chapel, wadham College.

section of a perpendicular window, and the other nondescript, as will be seen from the sections.

These striking differences have naturally induced a belief that the chapel was either a prior erection, or that the old materials of the Augustine convent, on the site of which the college was built, had been used up again ; but by the investigations of the Rev. J. Griffith, whose valuable paper on the subject gives the accounts referred to, it is clearly shown that the building of the two parts was carried on simultaneously. The foundress seems to have had a proper idea that a building used for Divine service should have a different character from those which were intended for domestic uses, and therefore, as the regular masons at that period could not

voL. VIII. 
have been much used to church work, and as it is shown by the accounts ${ }^{8}$ that the masons employed were brought to Oxford from a distance, it seems probable that she brought, from her own county of Somerset, workmen who had been used to this kind of work. The churches of Somersetshire are mostly of rich and late perpendicular character, and it is probable that the style might continue later there than in other places. It would, therefore, be a curious subject to inquire if any churches were built so late as that on which these masons might have been employed. The Hall of Wadham has an open timber roof, which is curious, as showing how, while the Gothic form was retained, the details were altered to suit the taste of the times. The large windor is a remarkable example of Jacobean tracery. The entrance under the principal gateway is groined, with fan vaulting, having in the centre the arms of the founder and foundress impaled.

The buildings of this period in Oxford are very numerous; indeed there are few colleges which have not some additions of this time; but it will not be necessary to do much more than enumerate the most favourable examples, with their dates.

The inner quadrangle of Merton College is stated to have been built by J. Bentley, one of the builders of the Schools, and the gateway into the gardens is an evident imitation of that of the Schools. It has four of the orders, and the spaces between are flled with Gothic panelling, but the effect is poor and flat. The external front of this part, which faces Merton, is, however, a very good composition, and embowered as it is with trees, has quite the character of one of the fine old mansions of the Elizabethan or Jacobean period.

8 In these accounts, (for an opportunity of examining which $I$ am indebted to the Rev. J: Griffith, the Sub-Warden), the masons who worked the stone for building are called Free masons, or Freestone Masons (which is probably the true meaning of the term), while the rest are merely called "labourers." The cost of each window, with the name of the workman, is put down separately, the price of a chapel window being $6 l$. while those of the hall, were $3 l .18 s$. each. It is curious, too, to find that the three statues over the entrance to the hall and chapel were cut by one of the free masons (William Blackshaw) employed on the other parts of the building. For each statue he was paid the sum of $3 l$.

The following prices and terms also appear, and are curious and interesting.

Lodgement, $4 d$. per foot.

Window table, $4 d$. per foot.

Grass table, $4 d$. per foot.

Window lights, 3s. $4 d$. each.

Pillar stone, at $16 d$. per foot.

Cornish, 2d. per foot.

Gorgel table

Gargill

Gurgul

Gurgoll at $4 d$. per foot.

Tun stone, or tun stuff 7 stones for

Tounel stones, or tunnel chimney stones 
EXAMPLES OF LATE GOTHIG BUILDINGS IN OXFORD.

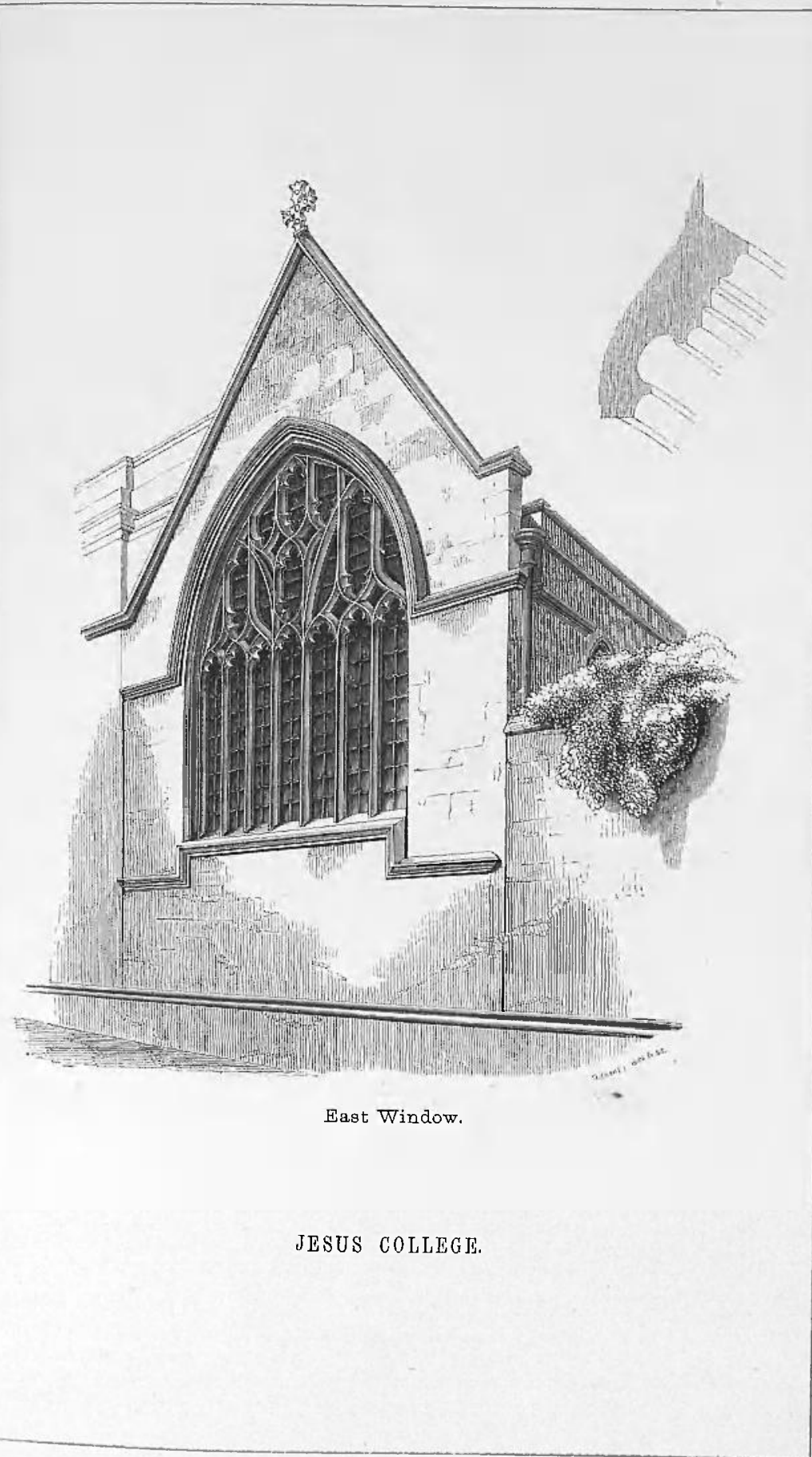


EXAMPLES OF LATE GOTHIC BUILDINGS IN OXFORD.

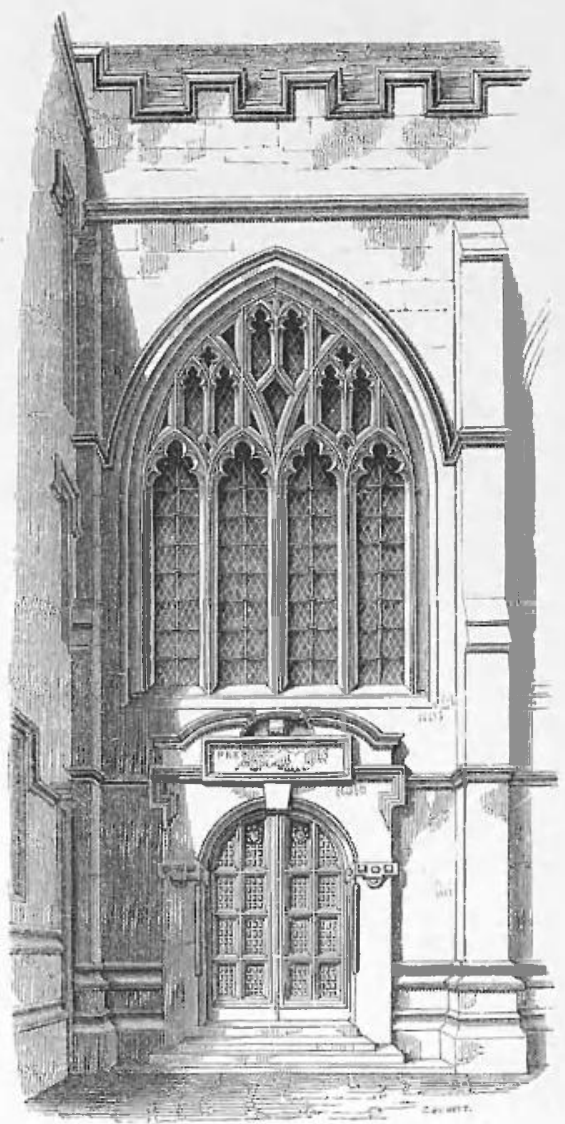

Entrance to the Chapel.

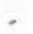

EXETER COLLEGE. 
EXAMPLES OF LATE GOTHIC BUILDINGS IN OXFORD.

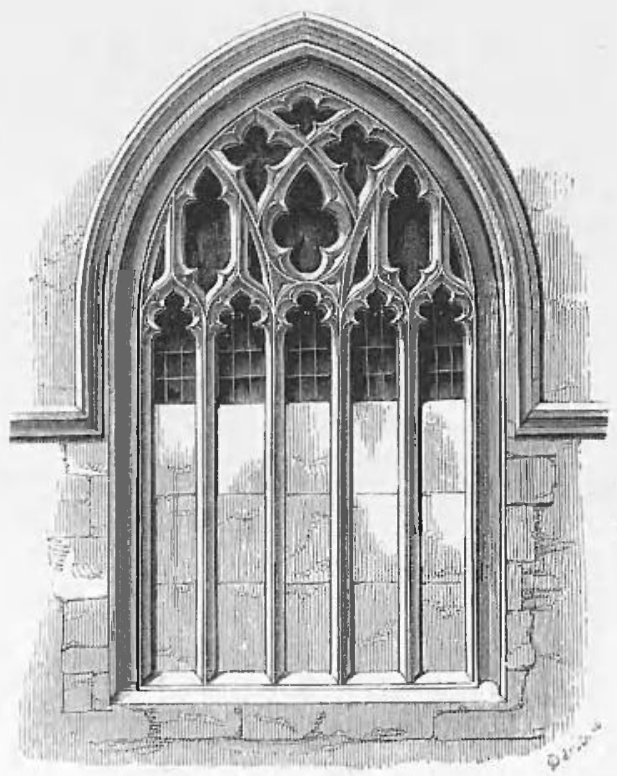

East Window.

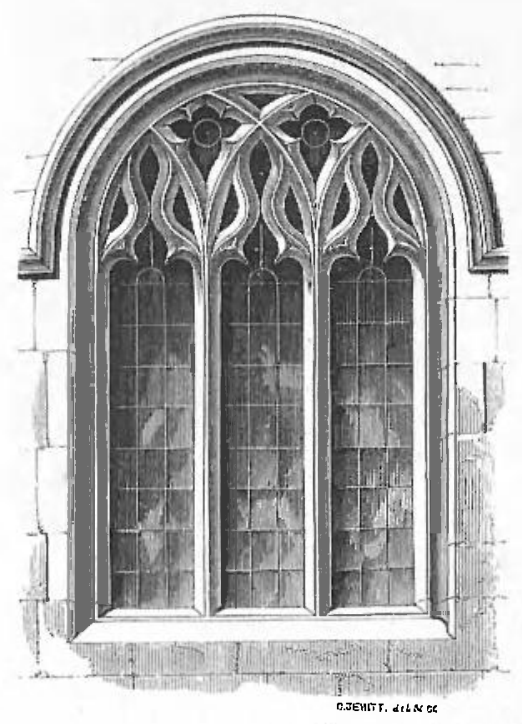

side Window.

ST. IIARI HALL 
The Hall of Trinity College, built in 1618 to 1620 , has good perpendicular windows.

Jesus College Chapel, built in 1621, and the east window of the chapel, which was added in 1636, are much better than might have been expected at the period, but there is no subordination of tracery, which all springs from the same fillet.

The Chapel of Exeter College, built in 1624, is a better specimen than the last. The tracery of the windows seems to have been copied from New College, and the subordination is preserved. The door, however, is completely of Jacobean character.

The second quadrangle of St. John's, which was built by Archbishop Laud between 1631 and 1636, is remarkable, and different from anything else in Oxford. It is by Inigo Jones, and the effect of the garden front is highly picturesque, and the combination of the Gothic forms with Elizabethan details skilfully managed. This mixture of styles, though it will not bear examination in detail, produces in the mass an effect highly pleasing; and harmonising so well as it does with the foliage by which it is surrounded, it seems well suited for the purpose for which it is here employed. The quadrangle is on two sides supported on Doric columns and arches, the spandrels of which are filled with heads, and with emblems of the sciences and of the moral virtues.

The Hall and Chapel of St. Mary Hall were built between the years 1632 and 1644. The arrangement is curious and unusual, the hall occupying the lower story, and the chapel the upper. The windows of the hall are squareheaded, but those of the chapel on the north and south sides are roundheaded, with intersecting tracery. The filling up of the heads of the lights is singular. The tracery, which assumes something of a Flamboyant form, springs from the chamfer in the manner of a cusp, and its fillets do not touch in the middle. The east window is pointed, and of five lights, with a mixture of intersecting and perpendicular tracery, the whole exhibiting a good example of that commingling of preceding styles which is so frequently found in late Gothic structures.

The Chapel of Lincoln College was built in 1631, and is one of the best examples of the period, the subordination of the tracery is preserved, and the mouldings are good, except 
one peculiarity, which seems to belong to this period, as it is

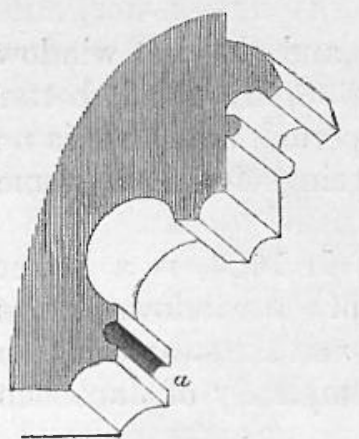

Section of Window.

Lincoln College Chapel. a. Grooved Fillet. found likewise at Oriel and other places. This is, - the fillet is left broad, and is grooved down the centre with a rather deep channel. This has the effect of dividing the fillet into two lines, and produces a clumsy appearance.

Oriel College was built about 1620 , but the Hall and Chapel were begun in 1637, and finished in 1642 . The character of the building is poor and clumsy. The tracery is of very late character, and it has the grooved fillet above-mentioned. The entrance to the chapel is under a bay-window, which has an open parapet of scroll-work.

The windows of the Hall and Chapel of University College, which were built about 1640, are much like those of Oriel. The east window of the chapel is particularly bad. Both colleges are built with fractable gablets.

In the Chapel of Brazenose College, which was built between 1656 and 1666 , all traces of Gothic, except the windows and roof, seem to have vanished. The exterior is Corinthian, with pointed windows inserted between the pilasters. The tracery is of rather early form, and the whole is a very incongruous mixture. In the east and west windows even the tracery is altered, and the oval form introduced, so that this may be taken as one of the last and most curious examples of the decline of Gothic before its extinction. The roof of the chapel, which is a kind of hammer beam with fan vaulting above, was brought from the chapel of St. Mary's College, which formerly stood in the Corn Market, and which was founded by Henry VI. in 1435. This kind of vaulting seems to have retained its hold longer than any other feature of the Gothic styles, unless it be the windows. It is extensively used in Oxford under gateways and other small spaces, as at Wadham, University, St. John's, \&c., but the finest specimen of it is the beautiful staircase to the Hall of Christ Church; and it is remarkable to find that it was erected so late as 1640 ; but it is stated by Peshall to have been built by Dean Fell, "by the help of — Smith, an 
artificer of London." Who Smith of London may have been, or whether he executed any other works beside this, does not seem to have been ascertained; but certainly this work alone, executed at a time when Gothic architecture everywhere else was sunk in utter debasement, ought to rescue his name from oblivion. Its chief fault is a want of boldness in the ribs, but this flatness was a fault of the time, which he did not overcome.

It has been generally considered that the whole of the work outside of the Hall was of this date, but it will be erident on examination that the two open doorways opposite the Hall-door, as well as the arches and doorways under the landing, are of Wolsey's time ; all the details and the boldness of the work show them to belong to his building. The parts, therefore, which Smith executed were the central pillar, and the vaulting which it supports, the steps, and parapets. This part, it seems, was left unfinished by Wolsey. The steps were not completed, and it was not roofed. It is, therefore, possible, as this design harmonises so well with the rest of the building, that the original drawings might have been preserved, and the present staircase built from them; but whoever was the designer, it stands as one of the most beautiful things in Oxford, and one which no visitor should omit seeing.

The buildings hitherto described or mentioned are all in Oxford, but there is another in its immediate neighbourhood which is worth notice; this is Water Eaton, a house which appears to have been built in the beginning of James I.'s reign, and to have been the residence of Lord Lovelace. It is now a farm-house, but remains in a perfect and almost unaltered state. The house has transomed windows and a projecting porch, ornamented with pillars and pilasters. It has a large court-yard, with a detached building for offices on each side of the gateway in front. On the north side of the court-yard is the chapel, having a yard on the south side. It is this building which is remarkable, as it remains almost in the same state as when built, the screen, pulpit, and open seats being the same as when first put in, and the building, though late, has scarcely any mixture of the later style.

The plan consists of a nave and chancel, divided by a chancel arch and screen, and having diagonal buttresses at 
all the angles. There are no windows on the north side, but on the south the nave has two, and the chancel one, and there are an east and west window, and a door on the south side. The doorway is pointed under a square label. The arches of the windows are much depressed, but slightly pointed; the lights are foliated and carried up to the head without tracery. The east window has five lights, and the others three lights each. The mouldings are of late character, but not debased. The bell-cot and cross are modern. The interior is very plain ; the chancel arch is semicircular, without mouldings, but has a screen closed with doors ; this is in the taste of the times, and is formed of semicircular arches, supported by small pillars, the whole carved with Elizabethan ornaments. The pulpit is a good specimen of this same style. The standards of the open seats are, as is usual at this period, rude, clumsy, and massive, the poppies being in imitation of the more ancient fleur-de-lis. The roof is a

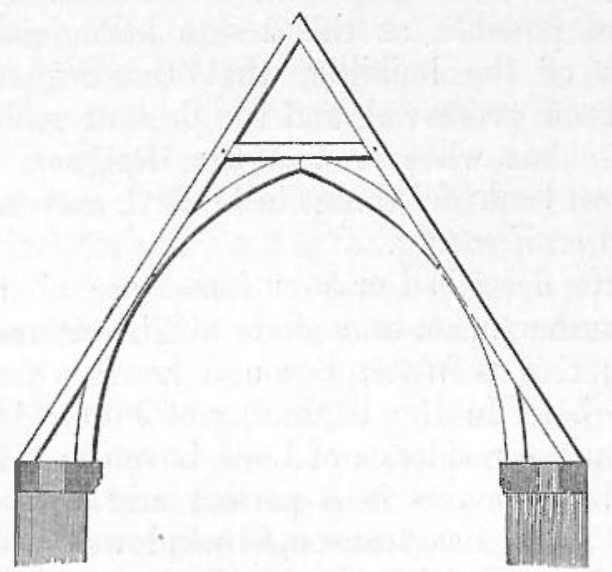

Roof of Chapel, Water Eaton. copy of an early form, and consists of principals, collar and curved braces, very plain and simple, but producing a good effect.

This building is interesting from showing that here, as at Wadham College before mentioned, though the house was built in the revived manner, it was still thought necessary to

keep the chapel in the old style, that being considered even then as exclusively ecclesiastical.

In the foregoing remarks, though very imperfectly executed, it has been intended to show by the buildings of Oxford, not only the gradual decline of Gothic architecture, but also the attempts, more or less successful, which were made from time to time to stay its progress. It was, however, for a time doomed to perish, and no efforts could save it. In the buildings of the period following that which 
has here been spoken of, it is either wholly laid aside, or the only remains of it are to be found in the accidental insertion, as it were, of a traceried window or a pointed door, as if to show that some faint recollections of the once-honoured forms still lingered in the minds of the architects, and caused them involuntarily to record their respect for it.

It would be an interesting investigation to trace the gradual awakening of the style from the deep slumber into which it had fallen, and to trace its gradual unfolding, step by step, until we have at length a more glorious rénaissance of the Gothic styles than we ever had of the Classic, and in this history no mean place would be assigned to the Architectural Society of Oxford.

O. JEWITr.

The following list will form an useful appendix to the foregoing :-

LATE GOTHIC BUILDINGS IN OXFORD, FROM THE REIGN OF ELIZABETII TO THE END OF THE SEVENTEENTH CENTURY.

Euz, 1571. The old buildings of Jesus College commenced.

1596. Library, St. John's College built.

1597. Sir Thomas Bodley commenced the repairs of Duke Humphrey's Library, and added the new roof.

1600. Front of St. Alban Hall built.

1602. Nov. 8. Duke Humphrey's Library publicly re-opened after the repairs.

IAs. I. 1610. July 16. First stone of the Bodleian Library and Proscholium laid.

1610. Great or main quadrangle of Merton built.

1610. July 31. First stone of Wadham College laid.

1612. West side of the lesser quadrangle of Lincoln College built.

1613. March 30. First stone of the Schools laid.

1613. April 20. Wadham College opened.

1617. Hall of Jesus College built.

1620. Hall of Trinity College finished.

1621. May 28. Chapel of Jesus College consecrated.

1624. Chapel of Exeter College built.

CI. I. 1626. Libiary of Jesus College built.

1628. Front of the house in St. Aldates, known as "Bishop King's House," built.

1630. Staircase of Christ Church Hall built.

1631. July 26. First stone of the Garden front and lesser quadrangle of St. John's College laid.

1631. Sept. 15. Chapel of Lincoln College consecrated.

1634. West side of University College built. 
1635. West side of St. Edmund Hall built.

1635. June 19. Front of University College commenced.

1637. Oriel College quadrangle and hall built.

1639. Chapel of University commenced ; finished in 1665.

1639-40. St. Mary Hall Chapel and Hall built.

1640. Hall of University College commenced. Finished in 1657.

1642. June or July. Oriel College Chapel consecrated.

1656. June 26. Chapel of Brazenose College, first stone laid; finished in 1666.

1663. Library of Brazenose College opened.

1665. March 30. Chapel of University College consecrated.

1666. Nov. 17. Chapel of Brazenose College consecrated.

1669. Library of University College opened.

\section{ON A REMARKABLE OBJECT OF THE REIGN OF AMENOPHIS III.}

PRESENTED TO THE EGYPTIAN COLLEGTION IN THE BRITISH MUSEUM BY THE LATE MARQUIS OF NORTHAMPTON.

TuE following observations are intended to illustrate two objects obtained by the late lamented President of the Institute, during his tour in Egypt in 1849. Independently of the historical or antiquarian importance of these curious relics, the following notices will be received with more than ordinary interest, as a tribute of respect to the memory of that lamented nobleman, and a memorial of one of the last acts of his wonted liberality in the furtherance of science.

The first is a thin slice, or veneer of ebony, 20 inches long, one inch wide, and about one-tenth of an inch thick. On it is incised, at the upper end, a mortaise, $\frac{3}{4}$ in. l., $\frac{1}{4}$ in. W., into which was inserted the tenon of the second, a stud of the usual mushroom shape, also of ebony, on which are also engraved two cartouches. On both these the hieroglyphs had been inlaid in white colour. They formed part of a box, and an example of how they were arranged on the cover is illustrated by No. 5907 in the British Museum, where the hieroglyphs, although only painted, are disposed in the same manner. When the historical value of these two objects, and the light which they throw upon a most difficult point of the history of the eighteenth dynasty, was 